\title{
PENGARUH METODE PERLAKUAN DALAM PERAWATAN BETON TERHADAP KUAT TEKAN DAN DURABILITAS BETON
}

\author{
Fepy Supriani ${ }^{1)}$, Mukhlis Islam ${ }^{2)}$ \\ ${ }^{122}$ Dosen Program Studi Teknik Sipil, Fakultas Teknik UNIB, Jl. W. R. Supratman, \\ Kandang Limun, Bengkulu 38371, Telp. (0736)344087 \\ e-mail : fepy_ilham@yahoo.co.id
}

\begin{abstract}
Abstrak
Kekuatan beton dipengaruhi oleh banyak hal, diantaranya oleh material penyusunnya, rancangan campuran, pengerjaan, dan perawatan. Tujuan perawatan beton adalah memelihara beton dalam kondisi tertentu pasca-pembukaan bekisting agar optimasi kekuatan beton dapat dicapai mendekati kekuatan yang telah direncanakan. Penelitian ini bertujuan untuk mengetahui pengaruh perlakuan perawatan beton terhadap kuat tekan beton. Beton rencana $20 \mathrm{MPa}$, dengan slump 60-100 mm. Benda uji berbentuk kubus dengan sisi $15 \mathrm{~cm}$. Pengujian kuat tekan dilakukan umur 28 hari dan 56 hari. Perlakuan perawatan beton terdiri dari 9 variasi yaitu, tidak dirawat, perendaman, dan penyiraman. Hasil kuat tekan optimum pada umum 28 hari dihasilkan oleh beton dengan perlakuan perawatan perendaman dengan air tawar yaitu sebesar 31,3 MPa. Beton dengan perlakuan diletakkan di luar ruangan tanpa perawatan memiliki nilai kuat tekan tertinggi kedua yaitu sebesar 28,6 MPa. Nilai kuat tekan beton yang dirawat dengan penyiraman dan ditutup karung goni untuk pengujian 28 hari masih dibawah kuat tekan beton yang tidak dirawat. Perubahan signifikan untuk kekuatan beton yang dirawat terjadi pada umur 56 hari dan beton yang tidak dirawat mengalami penurunan kekuatan sampai 19\%. Kenaikan optimum terjadi pada beton yang dirawat dengan ditutup karung goni dan disiram rutin selama 3 hari sebesar $27,84 \%$. Dengan bertambahnya umur (durability) beton yang dirawat memiliki kekuatan yang lebih baik.
\end{abstract}

Kata kunci: perlakuan perawatan beton, kuat tekan beton, durabilitas beton

\begin{abstract}
Concrete strength is influenced by several variables, among others by its constituent material, mix design, workmanship, and curing. The objective of concrete curing is to maintain the concrete in certain conditions after the dismantling of the formwork hence the optimization of concrete strength can be achieved close to the designed strength. This study aims to determine the effect of concrete curing on its compressive strength. Designed concrete compressive strength of 20 MPa with slump values of 60-100 mm to be used. The specimens are cube-shaped with $15 \mathrm{~cm}$ dimension. Concrete compressive strength tests were conducted at 28 days and 56 days of concrete age. The types of concrete curing consist of 9 variations, i.e., not treated, water immersed and water sprinkling. Optimum 28 days age of compressive strength of concrete obtained from specimens that immersed in fresh water, which was 31,3 MPa. The concrete specimens that were put outdoor without any curing and treatment generates second highest compressive strength value of $28.6 \mathrm{MPa}$. The 28 days age of concrete compressive strength values cured with water sprinkling with addition of burlap wrapping are still under the compressive strength of uncured concrete. Significant changes to the strength of cured concrete occurred at age of 56 days and uncured concrete strength decreased up to 19\%. The optimum increase occurred in concrete cured with burlap sack wrapping and water sprinkling that was conducted routinely for 3 days by 27,84\%. With increasing age (durability) the treated concrete has better strength.
\end{abstract}

Keywords: concrete curing, concrete compressive strength, concrete durability 


\section{PENDAHULUAN}

Pembangunan infrastruktur membutuhkan kualitas dan spesifikasi yang memadai. Kualitas pekerjaan ditentukan oleh tahapantahapan pekerjaan yang dilakukan. Tahapan yang juga penting adalah pada saat perawatan beton pasca dicetak. Tujuan perawatan beton adalah memelihara beton dalam kondisi tertentu pasca-pembukaan bekisting (demoulding of form work) agar optimasi kekuatan beton dapat dicapai mendekati kekuatan yang telah direncanakan.

Perawatan ini berupa pencegahan atau mengurangi kehilangan/ penguapan air dari dalam beton yang ternyata masih diperlukan untuk kelanjutan proses hidrasi. Bila terjadi kekurangan/kehilangan air maka proses hidrasi akan terganggu/terhenti dan dapat mengakibatkan terjadinya penurunan perkembangan kekuatan beton, terutama penurunan kuat tekan, di samping akan terjadinya penyusutan yang prematur sehingga menyebabkan retak-retak sebelum struktur bekerja.

Sehari setelah pengecoran merupakan saat yang terpenting untuk periode sesudahnya, oleh sebab itu diperlukan perawatan dengan air sehingga untuk jangka panjang, kualitas beton baik kekuatan maupun kekedapan airnya dapat lebih baik (Amri, 2005). Perawatan beton merupakan prosedur yang digunakan untuk membantu mempercepat proses hidrasi beton, menjaga kestabilan temperatur, dan perubahan kelembaban di dalam maupun di luar beton itu sendiri. Bila terjadi kekurangan/ kehilangan air maka proses hidrasi akan terganggu/terhenti dan dapat mengakibatkan terjadinya penurunan perkembangan kekuatan beton, terutama penurunan kuat tekan (Lubis dalam Indrayurmansyah, 2001).

Penguapan dapat menyebabkan beton kehilangan air yang cukup berarti, sehingga mengakibatkan terhentinya proses hidrasi, dengan konsekuensi berkurangnya peningkatan kekuatan (Neville, 1995).

Menurut Nugraha (2007), struktur beton harus mampu menghadapi kondisi dimana beton direncanakan, tanpa mengalami kerusakan (deteriorate) selama jangka waktu yang direncanakan.

Berbagai cara telah banyak dilakukan untuk mempertahankan kekuatan beton, yang dilaksanakan dengan memberikan perlakuan khusus pada beton mulai dari hari pengecoran sampai beton berumur 28 hari dimana beton akan mencapai kuat tekan $100 \%$ dari yang direncanakan. Akan tetapi berbagai kondisi di lapangan membuat proses perawatan ini kurang berjalan dengan baik, dengan berbagai alasan mulai dari waktu, ketersediaan air, lokasi proyek, jenis konstruksi dan lain-lain,sehingga seringkali perawatan ini terabaikan terutama untuk waktu 28 hari. Dari kenyataan di lapangan sebagaimana dimaksud, maka kualitas perawatan dipengaruhi oleh kondisi lapangan, metode yang digunakan dan kualitas beton hasil konstruksi itu sendiri.

Penurunan kualitas atau kuat tekan beton sendiri seharusnya, masih dalam dalam batas-batas toleransi dan memenuhi kondisi batas struktur dimana kondisi batas merupakan fungsi dari kekuatan (strength), kemampulayanan (serviceabllity), stabil (stable), berumur panjang (durable), dan sebagainya. Besaran penurunan kualitas ini juga akan digunakan sebagai dasar langkah antisipasi yang harus dimulai dari tahap perencanaan sampai dengan tahap perawatan bangunan, sehingga diharapkan akan didapatkan struktur yang tetap memenuhi kondisi batas tersebut namun tetap efisien dalam penggunaan sumberdaya selama masa konstruksi.

Banyak cara yang dilakukan untuk perlakuan perawatan beton, diantaranya metode pembasahan dengan air, dengan 
penguapan,dan dengan penggunaan membran(http://kampussipil.blogspot.com/ 2013/03/cara-perawatanbetonterbaru.html).

Rumusan masalah pada penelitian ini adalah seberapa besar pengaruh dari perawatan terhadap mutu beton melalui parameter kuat tekan beton, dimana dilakukan dengan beberapa perlakuan perawatan. Selanjutnya perlakuan yang bagaimana yang dapat menjadi metode yang efisien dan tetap mempertahankan mutu beton atau dengan penurunan kualitas yang seminimal mungkin, sehingga tetap memenuhi kondisi batas bukan hanya pada umur awal, melainkan untuk mutu beton dalam jangka panjang, dalam hal ini akan diketahui mutu beton dengan pertambahan usia.

Penelitian ini dilakukan bertujuan untuk mengetahui perlakuan perawatan yang paling optimal dan pada umur beton berapa hari yang perlu dilakukan perawatan yang lebih khusus. Sehingga penelitian ini selain perlakuan kondisi, juga memvariasikan waktu-waktu perawatan jika tidak memungkinkan dilakukan perawatan selama 28 hari, sebagai pembanding akan dilihat beton yang dirawat pada umur 3 hari, 14 hari, dan 28 hari dengan perlakuan yang ada.

Selain itu dengan bertambahnya waktu maka umur pelayanan beton akan semakin turun, durabilitas atau ketahanan beton terhadap penambahan waktu akan dilihat dari pengujian pada umur 56 ke depan, dengan perlakuan perawatan yang sama. Sebagai pembanding dibuat sampel beton yang tidak dilakukan perawatan, sehingga dapat dilihat kenaikan/penurunan mutu beton berdasarkan pengujian kuat tekan beton.

\section{METODE PENELITIAN}

Penelitian ini menerapkan metode eksperimen, yaitu penelitian yang bertujuan untuk menyelidiki hubungan sebab akibat antara satu sama lain dan membandingkan hasilnya. Penelitian ini dilakukan dengan cara membuat variasi perlakuan perawatan benda uji dengan tujuan mencari kuat tekan yang paling optimal setelah dilakukan beberapa variasi perlakuan perawatan beton.

Peneliti melakukan beberapa perlakuan kondisi perawatan beton yang efisien, dan mendekati kondisi lapangan, yaitu metode pembasahan seperti menyelimuti permukaan beton dengan karung goni basah, menyirami permukaan beton dengan air secara kontinyu, dan juga memvariasikan waktu perawatan beton selama 26 hari. Sehingga bisa diketahui apakah variasi perlakuan perawatan beton yang dilakukan mempunyai pengaruh terhadap kuat tekan beton.Selain itu juga untuk mengetahui perlakuan yang bagaimana yang optimal dan ideal dalam menjaga mutu beton yang direncanakan.

Perlakuan perawatan beton yang dilakukan pada penelitian ini adalah sebagai berikut terlihat pada Tabel 1. Benda uji dibuat dalam bentuk kubus dengan dimensi $15 \mathrm{~cm}$ x 15 $\mathrm{cm} \times 15 \mathrm{~cm}$. Kuat beton rencana (fc') 20 Mpa, dengan nilai slump 60-100 mm. Perencanaan komposisi beton menurut peraturan Mix Desain SK SNI T-15-199003. Sifat fisis bahan pembentuk beton (semen, pasir dan agregat kasar) melalui pemeriksaan ini sesuai dengan SK-SNI-T15-1991-03.

Tiap perlakuan perawatan digunakan ratarata 5 buah sampel. Pada penelitian ini sampel di uji tekan pada umur 28 hari dan 56 hari untuk melihat perkembangan kuat tekan dari masing-masing sampel.

Air yang digunakan adalah air bersih, tidak berbau, tidak mengandung lumpur, tidak mengandung minyak dan tidak mengandung kotoran/sampah. SK SNI 03-2493-1991. 
Tabel 1. Kode Benda Uji

\begin{tabular}{|c|c|c|}
\hline No & Perlakuan Perawatan & $\begin{array}{c}\text { Kode } \\
\text { Benda Uji }\end{array}$ \\
\hline 1 & $\begin{array}{l}\text { Perendaman dengan air } \\
\text { tawar selama } 26 \text { hari. }\end{array}$ & $\mathrm{V} 1$ \\
\hline 2 & $\begin{array}{l}\text { Dibiarkan di dalam } \\
\text { ruangan tertutup tanpa } \\
\text { perawatan selama } 27 \\
\text { hari }\end{array}$ & $\mathrm{V} 2$ \\
\hline 3 & $\begin{array}{l}\text { Dibiarkan di luar } \\
\text { ruangan tanpa } \\
\text { perawatan selama } 26 \\
\text { hari. }\end{array}$ & V3 \\
\hline 4 & $\begin{array}{l}\text { Diletakkan di luar } \\
\text { ruangan dengan } \\
\text { penyiraman pagi dan } \\
\text { siang selama } 3 \text { hari }\end{array}$ & V4 \\
\hline 5 & $\begin{array}{l}\text { Diletakkan di luar } \\
\text { ruangan dengan } \\
\text { penyiraman pagi dan } \\
\text { siang selama } 14 \text { hari }\end{array}$ & V5 \\
\hline 6 & $\begin{array}{l}\text { Diletakkan di luar } \\
\text { ruangan dengan } \\
\text { penyiraman pagi dan } \\
\text { siang selama } 26 \text { hari }\end{array}$ & V6 \\
\hline 7 & $\begin{array}{l}\text { Diletakkan di luar } \\
\text { ruangan, ditutup dengan } \\
\text { karung goni dan disiram } \\
\text { setiap pagi dan siang } \\
\text { selama } 3 \text { hari }\end{array}$ & V7 \\
\hline 8 & $\begin{array}{l}\text { Diletakkan di luar } \\
\text { ruangan, ditutup dengan } \\
\text { karung goni dan disiram } \\
\text { setiap pagi dan siang } \\
\text { selama } 14 \text { hari }\end{array}$ & V8 \\
\hline 9 & $\begin{array}{l}\text { Diletakkan di luar } \\
\text { ruangan, ditutup dengan } \\
\text { karung goni dan disiram } \\
\text { setiap pagi dan siang } \\
\text { selama } 26 \text { hari }\end{array}$ & V9 \\
\hline
\end{tabular}

\section{Tahap perawatan benda uji}

Perlakuan perawatan yang dilakukan terhadap benda uji pada penelitian ini adalah sebagai berikut:
1. Perendaman dengan air

Cetakan dibuka setelah 24 jam, sampel diberi kode V1, kemudian sampel beton dibawa, dan direndam dalam bak yang berisi air tawar selama 26 hari dari usia perawatan.

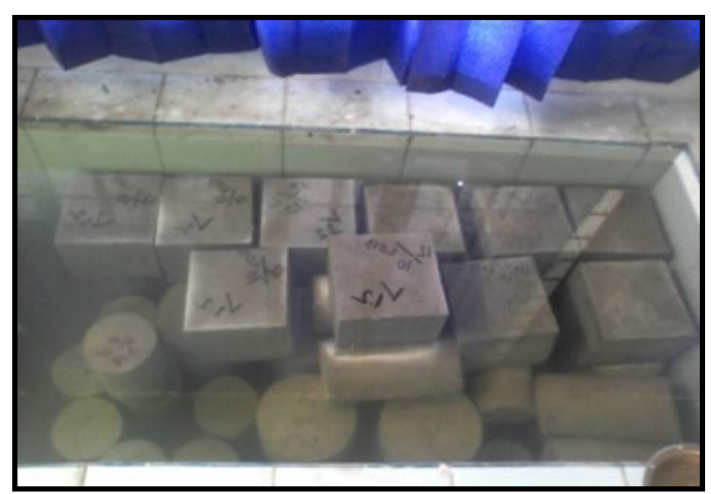

Gambar 1. Perendaman (V1)

2. Dibiarkan di dalam ruangan tanpa perawatan

Setelah cetakan dibuka, sampel beton diberi kode V2, kemudian sampel beton dibawa, dan diletakan di dalam ruangan tertutup/dibiarkan tanpa diberi perawatan selama 27 hari. Beton ini mewakili beton yang tidak dirawat tapi masih terlindung dengan kondisi luar.

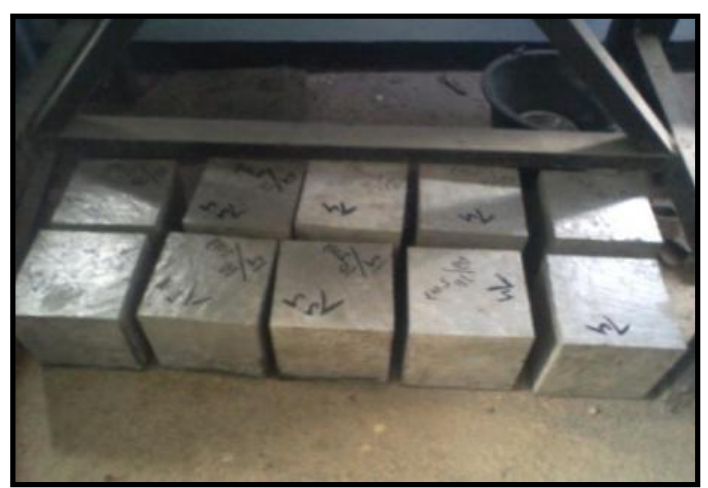

Gambar 2. Dirawat di dalam ruangan

3. Dibiarkan di luar ruangan tanpa perawatan

Setelah cetakan dibuka, sampel beton diberi kode V3, kemudian sampel beton dibawa, dan diletakan di luar ruangan tanpa pelindung/atap, serta tidak diberi perawatan selama 26 hari. Beton ini dibiarkan terkena pengaruh luar seperti sinar matahari, angin dan hujan. 


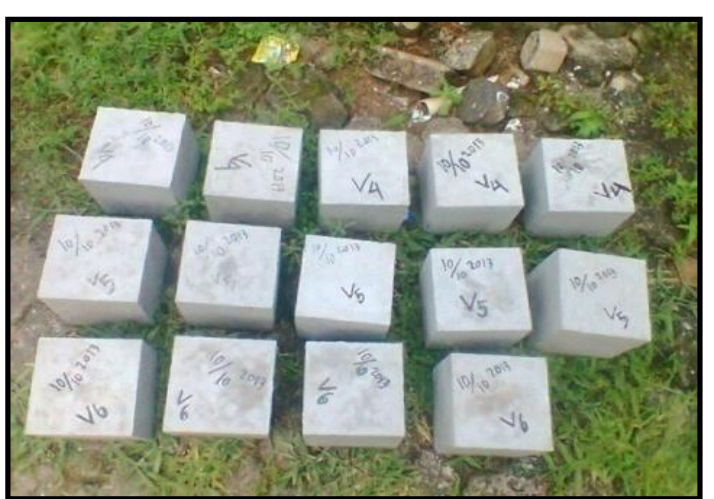

Gambar 3. Di Luar Ruangan

4. Diletakan di luar ruangan, disiram pagi dan siang selama 3 hari

Setelah cetakan dibuka, sampel beton diberi kode V4, kemudian sampel beton dibawa, dan diletakan di luar ruangan tanpa pelindung/atap, selanjutnya disiram pagi dan siang selama 3 hari.

5. Diletakan di luar ruangan, disiram pagi dan siang selama 14 hari

Setelah cetakan dibuka, sampel beton diberi kode V5, kemudian sampel beton dibawa, dan diletakan di luar ruangan tanpa pelindung/atap, selanjutnya disiram pagi dan dan siang selama 14 hari.

6. Diletakan di luar ruangan, disiram pagi dan siang selama 26 hari

Setelah cetakan dibuka, sampel beton diberi kode V6, kemudian sampel beton dibawa, dan diletakan di luar ruangan tanpa pelidung/atap, selanjutnya disiram pagi dan siang selama 26 hari.

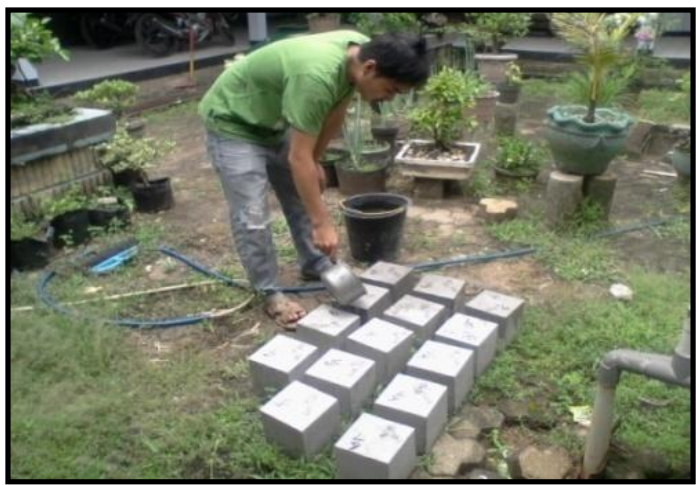

Gambar 4. Perawatan di Luar Ruangan dengan Penyiraman
7. Diletakan di luar ruangan, ditutup karung goni, lalu disiram pagi dan siang selama 3 hari

Setelah cetakan dibuka, sampel beton diberi kode V7, kemudian sampel beton dibawa, dan diletakan di luar ruangan tanpa pelindung/atap, lalu ditutup dengan karung goni, selanjutnya disiram pagi dan siang selama 3 hari.

8. Diletakan di luar ruangan, ditutup karung goni, lalu disiram pagi dan siang selama 14 hari

Setelah cetakan dibuka, sampel beton diberi kode V8, kemudian sampel beton dibawa, dan diletakan di luar ruangan tanpa pelindung/atap, lalu ditutup dengan karung goni, selanjutnya disiram pagi dan siang selama 14 hari.

9. Diletakan di luar ruangan, ditutup karung goni, lalu disiram pagi dan siang selama 26 hari

Setelah cetakan dibuka, sampel beton diberi kode V9, kemudian sampel beton dibawa, dan diletakan di luar ruangan tanpa pelindung/atap, lalu ditutup dengan karung goni, selanjutnya disiram pagi dan siang selama 26 hari.

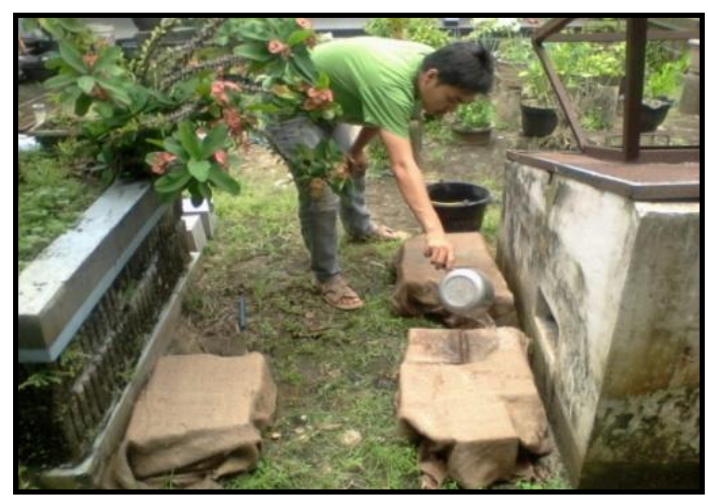

Gambar 5. Perawatan di luar ruangan dengan Penyiraman dan ditutup karung goni

\section{Pengujian kuat tekan}

Mulyono (2004) mengemukakan bahwa kuat tekan beton mengidentifikasikan mutu sebuah struktur dimana semakin tinggi tingkat kekuatan struktur yang dikehendaki, 
maka semakin tinggi pula mutu beton yang dihasilkan. Berdasarkan SK-SNI-T-151990-03 nilai kuat tekan dihitung dengan rumus:

$$
\sigma=\mathrm{P} / \mathrm{A}
$$

Dimana :

$\sigma=$ Kuat tekan beton $(\mathrm{MPa})$

$\mathrm{P}=$ Beban maksimum $(\mathrm{kg})$

$\mathrm{A}=$ Luas penampang benda uji $\left(\mathrm{cm}^{2}\right)$

Pengujian kuat tekan benda uji adalah untuk beton yang direndam (V1), beton diangkat dari rendaman ketika berumur 27 hari, kemudian dianginkan selama 24 jam. Sedangkan untuk beton V2 saat berumur 27 hari, beton dipindahkan ke tempat yang mudah dijangkau, lalu dianginkan selama 24 jam. Sementara untuk beton V3, V4, V5, V6, V7, V8, dan V9 dimasukkan ke dalam ruangan saat berumur 27 hari, kemudian dianginkan selama 24 jam. Pengujian kuat tekan beton, benda uji diletakkan ke dalam alat uji tekan (Universal Compression Testing Machine), lalu mesin uji tekan dihidupkan dan secara perlahan alat menekan benda uji.

\section{HASIL DAN PEMBAHASAN}

\section{Nilai kuat tekan beton}

Setelah mencapai umur rencana maka dilakukan pengujian kuat tekan beton pada umur 28 hari dan 56 hari. Pengujian ini bertujuan untuk melihat perbedaan kuat tekan beton dari beberapa metode perawatan dan beton yang tidak dirawat.

Hasil pengujian kuat tekan beton yang dirawat dan kuat tekan beton yang tidak dirawat dapat dilihat pada Tabel 2.
Tabel 2. Hasil uji kuat tekan beton rata-rata

\begin{tabular}{|c|c|c|c|}
\hline $\begin{array}{c}\text { No } \\
\text { sampel }\end{array}$ & $\begin{array}{c}\text { Kode } \\
\text { sampel }\end{array}$ & $\begin{array}{c}\text { Kuat tekan } \\
\text { rata-rata } \\
\text { (MPa) } \\
28 \text { hari }\end{array}$ & $\begin{array}{c}\text { Kuat tekan } \\
\text { rata-rata } \\
\text { (MPa) } \\
56 \text { hari }\end{array}$ \\
\hline 1 & V1 & 31,3 & 33,6 \\
\hline 2 & V2 & 26,8 & 22,36 \\
\hline 3 & V3 & 28,6 & 25,7 \\
\hline 4 & V4 & 26,5 & 32,13 \\
\hline 5 & V5 & 26,8 & 32,21 \\
\hline 6 & V6 & 26,3 & 34,39 \\
\hline 7 & V7 & 22,6 & 31,32 \\
\hline 8 & V8 & 22,8 & 31,42 \\
\hline 9 & V9 & 23,0 & 31,7 \\
\hline
\end{tabular}

Dari hasil uji kuat tekan pada Tabel 2 dapat disajikan grafik kuat tekan beton sebagai berikut pada Gambar 6 .

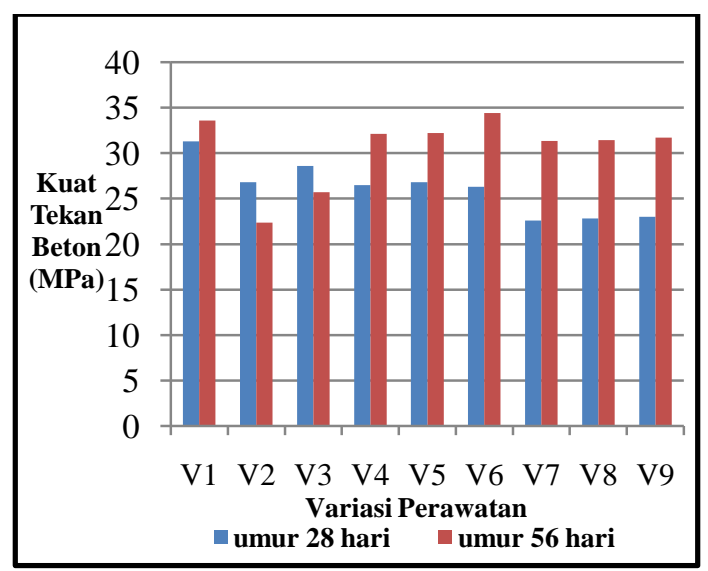

Gambar 6. Grafik Kuat Tekan Beton

Hasil uji kuat tekan beton pada umur 28 hari menunjukkan bahwa beton yang dirawat dengan cara direndam dalam air (V1) masih memiliki nilai kuat tekan rata-rata tertinggi yaitu sebesar 31,3 MPa. Mendekati kuat tekan rata-rata $\mathrm{V} 1$ adalah beton yang tidak dirawat dengan perlakuan diletakkan di luar ruangan tanpa perawatan (V3) dengan kuat tekan rata-rata 28,6 $\mathrm{MPa}$. Nilai kuat tekan terendah pada umur 28 hari dihasilkan oleh beton yang dirawat dengan perlakuan diletakkan di luar ruangan, lalu ditutup karung goni, dan disiram pagi, siang selama 3 hari (V7) yaitu sebesar 22,6 MPa. 
Pengujian kuat tekan beton umur 56 hari bertujuan untuk melihat perkembangan kekuatan umur beton yang dipengaruhi oleh metode perawatan, untuk umur 56 hari beton sudah mendapatkan pengaruh cuaca, suhu dan pengaruh alam lainnya.

Pada umur 56 hari kekuatan beton beton yang tidak dirawat mulai mengalami penurunan kekuatan, sedangkan beton yang dirawat baik yang direndam, disiram dan ditutupi karung goni mengalami peningkatan kekuatan pada umur 56 hari. Beton-beton yang dirawat dapat mencapai lebih dari 30 MPa.

Membandingkan kuat tekan beton rata-rata untuk umur 28 hari dan 56 hari bertujuan untuk melihat perkembangan kekuatan beton secara menyeluruh. Gambar 7 menunjukkan data perbandingan kuat tekan beton, semua beton yang tidak dirawat memiliki kekuatan dibawa beton yang dirawat baik dengan perendaman, penyiraman dan penutupan dengan karung goni basah. Selisih kuat tekan antara beton yang dirawat terhadap beton yang tidak dirawat, dapat dilihat pada Tabel 3 .

Tabel 3. Selisih Kuat Tekan Beton dengan Perlakuan Perawatan/ Tanpa Perawatan Umur 28 Hari dan 56 Hari

\begin{tabular}{|c|c|c|}
\hline \multirow{2}{*}{$\begin{array}{c}\text { Kode } \\
\text { Sampel }\end{array}$} & \multicolumn{2}{|c|}{ Kenaikan (+) / Penurunan (-) } \\
\cline { 2 - 3 } & $(\mathrm{MPa})$ & $\%$ \\
\hline V1 & 2,3 & 6,85 \\
\hline V2 & $-4,44$ & $-19,86$ \\
\hline V3 & $-2,9$ & $-11,28$ \\
\hline V4 & 5,63 & 17,52 \\
\hline V5 & 5,41 & 16,80 \\
\hline V6 & 8,09 & 23,52 \\
\hline V7 & 8,72 & 27,84 \\
\hline V8 & 8,62 & 27,43 \\
\hline V9 & 8,7 & 27,44 \\
\hline
\end{tabular}

Tabel 3 menunjukkan semua beton yang dirawat mengalami kenaikan kekuatan dari umur 28 hari ke umur 56 hari sedangkan beton yang tidak dirawat mengalami penurunan kekuatan seiring bertambahnya waktu. Beton yang tidak dirawat yang terletak diluar ruangan (V3) penurunan kekuatannya lebih kecil dibandingkan dengan tidak dirawat diluar ruangan karenan yang diluar ruangan masih memungkinkan mendapat perawatan alami dengan air hujan.

Gambar 7 menunjukkan bahwa nilai negatif yang berada dibawah titik nol terjadi pada beton yang tidak dirawat didalam ruangan (V2) dan tidak dirawat diluar ruangan (V3). Nilai positif menunjukkan kenaikan kuat tekan dari umur 28 hari ke 56 hari.

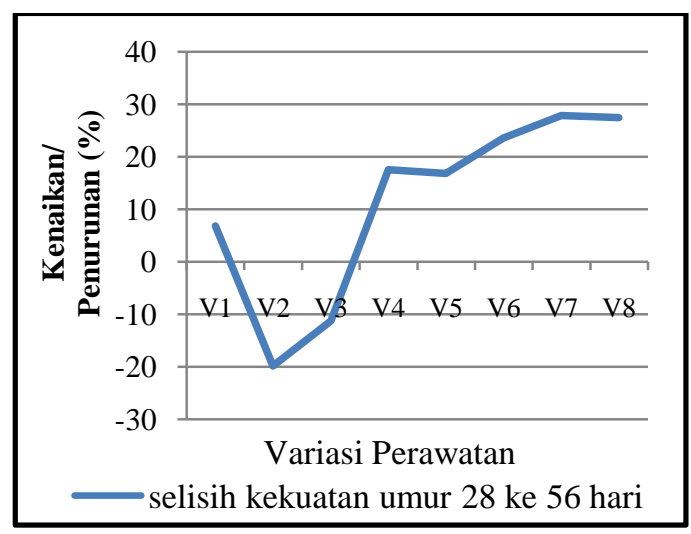

Gambar 7. Grafik Selisih Kuat Tekan Beton dengan Perlakuan Perawatan/ Tanpa Perawatan Umur 28 Hari dan 56 Hari

Beton yang direndam dengan air menunjukkan peningkatan terendah $(6,85 \%)$. Selanjutnya beton dengan perawatan penyiraman mengalami peningkatan kekuatan dengan semakin lamanya waktu penyiraman dari 3 hari, 14 hari dan 26 hari. Peningkatan kekuatan yang terbesar adalah perawatan dengan penutupan dengan karung goni dan disiram air, peningkatan kekuatan juga besar sesuai dengan waktu penyiraman 3 hari, 14 hari, dan 26 hari.

Hasil penelitian ini menunjukkan bahwa perawatan dengan menutup beton dengan 
karung goni dan dilakukan penyiraman rutin memberikan kekuatan yang semakin tinggi dengan bertambahnya waktu (durability). Kemungkinan terjaganya kestabilan temperatur, dan perubahan kelembaban di dalam maupun di luar beton karena beton terjaga dari kontaminasi pengaruhi luar sedangkan proses hidrasi dapat berjalan baik dengan melakukan penyiraman teratur. Di lapangan kedua metode perawatan dengan penyiraman dan penutupan karung goni basah dapat dilakukan, selain menjaga mutu beton juga meningkatkan kekuatan beton dengan bertambahnya umur beton, sedangkan perawatan perendaman beton cocok dilakukan di laboratorium.

\section{KESIMPULAN}

Kesimpulan yang dapat diambil dari penelitian ini adalah sebagai berikut:

1. Kuat tekan optimum pada umum 28 hari dihasilkan oleh beton dengan perlakuan perawatan perendaman dengan air tawar yaitu sebesar 31,3 MPa.

2. Beton dengan perlakuan diletakkan di luar ruangan tanpa perawatan memiliki nilai kuat tekan tertinggi kedua yaitu sebesar 28,6 MPa.

3. Nilai kuat tekan beton yang dirawat dengan penyiraman dan ditutup karung goni untuk pengujian 28 hari masih di bawah kuat tekan beton yang tidak dirawat.

4. Perubahan signifikan untuk kekuatan beton yang dirawat terjadi pada umur 56 hari dan beton yang tidak dirawat mengalami penurunan kekuatan sampai $19 \%$.

5. Kenaikan optimum terjadi pada beton yang dirawat dengan ditutup karung goni dan disiram rutin selama 3 hari sebesar $27,84 \%$.
6. Dengan bertambahnya umur (durability) beton yang dirawat memiliki kekuatan yang lebih baik.

\section{DAFTAR PUSTAKA}

Amri, S. 2005. Teknologi Beton A-Z. Penerbit Yayasan John Hi-Tech Idetama, Jakarta.

http://kampussipil.blogspot.com/2013/03/car a-perawatan-beton-terbaru.html. 16 September 2013 (Pkl 14.00 WIB).

Indrayurmansyah. 2001. Pentingnya Perawatan Beton untuk Mencapai Nilai Kekuatan. Jurnal R \& B. Vol. 1 No 2. Jurusan Teknik Sipil. Politeknik Negeri Padang.

Mulyono, T. 2003. Teknologi Beton. Andi Offset, Yogyakarta.

Neville, A.M. 1995. Properties of Concrete, Fourth and Final Edition. Longman Group Limited, England.

Nugraha, P., and Antoni, C. 2007. Teknologi Beton. Universitas Kristen Petra, Surabaya.

SK SNI 03-2493-1991. 1991. Metode Pembuatan dan Perawatan Benda Uji Beton di Laboratorium. Departemen Pekerjaan Umum Yayasan Badan Penerbit PU, Bandung.

SK SNIT-15-1990-03. 1990. Tata Cara Pembuatan Rencana Campuran Beton Normal. Departemen Pekerjaan Umum Yayasan Badan Penerbit PU, Bandung.

SK SNIT-15-1991-03. 1991. Tata Cara Perhitungan Struktur Beton untuk Bangunan Gedung. Departemen Pekerjaan Umum Yayasan Badan Penerbit PU, Bandung. 